ISA

Arboriculture \& Urban Forestry 2017. 43(3):89-106

\title{
A Review of Factors That Affect the Static Load- Bearing Capacity of Urban Trees
}

\author{
Gregory A. Dahle, Kenneth R. James, Brian Kane, Jason C. Grabosky, \\ and Andreas Detter
}

\begin{abstract}
Over the last 30 years, researchers have begun to employ biomechanical principles to understand the stability of urban trees. This review concentrates on literature pertaining to trees in temperate urban landscapes, but also includes relevant work from other disciplines and climates as appropriate. The load-bearing capacity of a tree depends on its size and shape and the material properties of its wood. As the trunk and branches increase in diameter, their load-bearing capacity increases. Material properties (e.g., moduli of elasticity and rupture) describe intrinsic wood stiffness and strength, which influence deflection under load and load-bearing capacity, respectively. In wood, material properties vary in relation to a variety of factors, including the direction of loading, moisture content, and tree age. Wood decay reduces a tree's load-bearing capacity. Although practitioners have developed guidelines to assess its effect, existing guidelines should be investigated, refined or rejected on the basis of rigorous scientific testing. Static load tests have been developed to address this question, as well as investigate the likelihood of uprooting, which accounts for up to $35 \%$ of tree failures. While much has been learned, many questions remain about the static load-bearing capacity of trees growing in urban landscapes.

Key Words. Allometry; Biomechanics; Decay; Literature Review; Material Properties; Modulus of Elasticity; Modulus of Rupture; SoilRoot Plate; Static Load Tests.
\end{abstract}

Biomechanics is the study of biological organisms from a mechanical perspective. Several monographs describe the literature on plant biomechanics (Niklas 1992; Vogel 1996; Niklas and Spatz 2012), and biomechanical investigations of plants are common in many basic and applied sciences (e.g., botany, ecology, evolutionary biology, forestry, and horticulture). Plant biomechanics seeks to understand how growth and development leads to a structurally stable plant that can withstand environmental and gravitational loading over its life span. Plant biomechanics applies well-known mechanical theories that were developed for engineering structures that use uniform materials, like steel and concrete. When these theories are applied to biological materials, some simplifying assumptions are used that may not always apply to the architecture of plants (Niklas 1992; Niklas and Spatz 2012). Authors readily acknowledge this limitation. Common and acknowledged simplifying assumptions include:
- Using equations that assume wood in living trees is homogeneous and isotropic, like engineering materials (e.g., steel or concrete) (Niklas 1992; Niklas and Spatz 2012)

- Using equations that are valid only for small deflections when regular geometric shapes are loaded (Niklas 1992; Niklas and Spatz 2012)

- Using static equations for wind load analysis (Hale et al. 2010)

Using simplifying assumptions is often necessary in the absence of more sophisticated analyti$\mathrm{cal}$ and measuring techniques or in the absence of knowledge of the species or situation in question. The geometry and material properties of engineered structures do not substantially change over time or in response to external stimuli, excepting material degradation due to fatigue or structural failure. In stark contrast, biological structures adapt material properties and morphology over their life span and in response to external stimuli 
(Jaffe 1973; Telewski and Jaffe 1986a; Telewski and Jaffe 1986b; Jaffe 2002; Telewski 2006; Dahle and Grabosky 2010b), as well as changing due to formation of different kinds of wood (e.g., callus or woundwood) (Kane and Ryan 2003).

The focus of this review is arboricultural biomechanics. Researchers primarily reviewed studies published in the last 30 years but included older sources and studies from other disciplines where appropriate. Biomechanical investigations in applied disciplines, like arboriculture and forestry, study the applied loads and loadbearing capacity of a tree; the focus for this review is on the latter. Loads and structural responses are often categorized as "static" or "dynamic," describing the duration of the load or structural response. Static implies a relatively long duration, where loads might be considered relatively constant (Peltola 2006). Self-weight and loads due to snow or ice are considered static loads. Dynamic implies a relatively short duration; the magnitude and direction of the load and structural response change quickly (James et al. 2006). Wind-induced tree sway is an example of dynamic load and structural response. While trees must continuously resist self-weight, Niklas (2000) suggested that wind is likely the most common cause of tree failure. In a companion manuscript (James et al. 2014), researchers reviewed the biomechanics literature that focused on tree dynamics.

This review focuses on urban trees in temperate climates and the intrinsic biomechanical factors that affect their static load-bearing capacity. This approach was chosen because arborists use biomechanics to estimate the likelihood of tree failure when assessing tree risk. Researchers organized the manuscript into the following sections: material properties of wood (strength, elasticity, ontogenetic changes); tree form (allometry and growth response); decay and the loss in load-bearing capacity; assessing the loadbearing capacity using static load tests; and root architecture and stability of the soil-root plate.

\section{MATERIAL PROPERTIES}

The material properties of wood determine its load-bearing capacity. The two most commonly measured material properties of wood are the elastic modulus $(E)$ and modulus of rupture $(M O R)$, which describe a material's stiffness and maximum load-bearing capacity, respectively (Table 1).

Wood is an anisotropic material, and its material properties are different in the longitudinal, radial, and tangential directions (Figure 1). An example of how Young's modulus $(E)$ values vary can be found with balsa wood: in three directions are longitudinal (in compression), $E_{L}=$ $3.12 \mathrm{GN} / \mathrm{m}^{2}$; radial, $E_{R}=0.144 \mathrm{GN} / \mathrm{m}^{2}$; and tangential, $E_{T}=0.0468 \mathrm{GN} / \mathrm{m}^{2}$ (Niklas 1992). Wood from trees growing in temperate climates is typically twice as strong in tension as compression in the longitudinal direction (Kretschmann 2010). Gordon (1991) suggests that there can be a difference as high as three or four times.

Depending on the line of action of a force, different types of stress develop in trees, including tension, compression, bending, shear, and torsion. The material properties of wood can be complex to describe (Table 1), and sometimes wood is considered to be orthotropic, with $E$ and $M O R$ varying longitudinally, tangentially, and radially. Differences in material properties can influence the failure mode of a tree, which has implications for assessing the likelihood of failure. Niklas (2002) points out that the literature on plant materials rarely provides elastic moduli for each direction, and studies frequently refer to a single $E$ value. Unless otherwise stated, this literature review refers to longitudinal $E$ and $M O R$ values.

$E$ and $M O R$ are often directly proportional to wood density in stems and branches (van

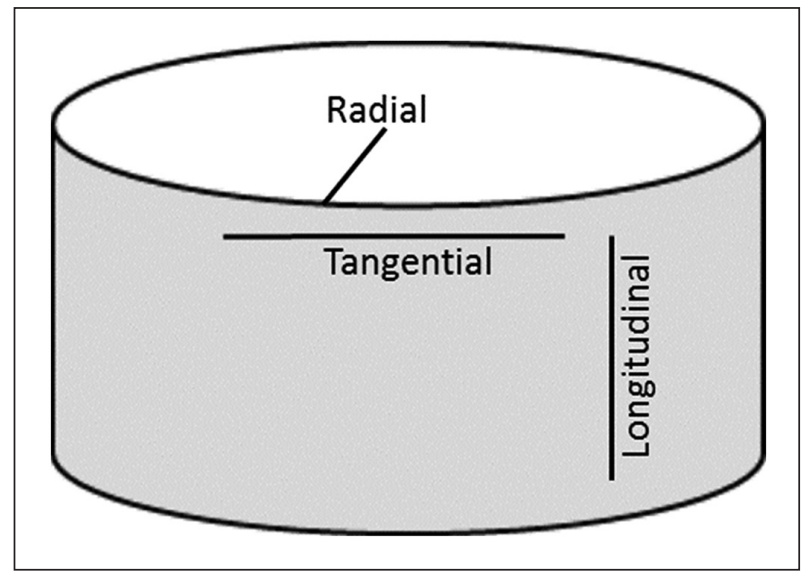

Figure 1. An example of Young's modulus ( $E$ ) of wood (balsa) in three directions. Longitudinal (in compression) $E_{L}=3.12$ $\mathrm{GN} / \mathrm{m}^{2}$, radial $E_{R}=0.144 \mathrm{GN} / \mathrm{m}^{2}$ and tangential $E_{T}=0.0468$ $\mathrm{GN} / \mathrm{m}^{2}$ (adapted from Niklas 1992). 
Table 1. Mechanical terms used in tree biomechanics adapted from Hibbeler (2005), Burgert (2006), and Kretschmann (2010).

\begin{tabular}{|c|c|}
\hline Member & A structural component of a tree that is under consideration; e.g., a stem, a branch, a root. \\
\hline Force & $\begin{array}{l}\text { Force is a quantity that causes a mass to accelerate. } \\
\mathrm{F}=\mathrm{m}^{\star} \text { a (Newton's second law of motion). } \\
\text { A force may act in many ways, e.g., } \\
\text { Pulling - tensile force } \\
\text { Pushing - compressive force } \\
\text { Sliding - shearing force }\end{array}$ \\
\hline Modulus of Rupture (MOR) & $\begin{array}{l}\text { A measure of maximum load-bearing capacity of a member, before it fails. For wood, } M O R \text { is usually measured in a } \\
\text { bending test, so } M O R \text { may be taken as the bending strength of wood. } M O R \text { is an acceptable measure of strength, yet } \\
\text { is not a true measure as the calculation is only valid in the elastic limit. }\end{array}$ \\
\hline $\begin{array}{l}\text { Modulus of Elasticity } \\
\text { symbol }(E)\end{array}$ & $\begin{array}{l}\text { A measure of a member's resistance to elastic deformation, which is typically determined from the slope of the line } \\
\text { in the linear portion of the stress-strain diagram. Also called Young's Modulus, or stiffness of the material. }\end{array}$ \\
\hline $\begin{array}{l}\text { Flexural stiffness } \\
\text { symbol }(E I)\end{array}$ & $\begin{array}{l}\text { The resistance of a member (usually a beam) in bending. Stiffness depends on a material's modulus of elasticity }(E) \\
\text { and its size and shape, which determines its moment of inertia }(I) \text {. }\end{array}$ \\
\hline Moment & $\begin{array}{l}\text { A twisting or bending that causes a rotation about a point. Usually considered as a combination of a force acting at } \\
\text { a distance to cause rotation about a point. For example, a wind force on a tree canopy pushes at a height (distance) } \\
\text { above the base of the trunk to create a moment at the base and the tree tends to rotate about this point. Moments } \\
\text { have the same unit as torque (e.g., } \mathrm{N}^{\star} \mathrm{m} \text { ). }\end{array}$ \\
\hline $\begin{array}{l}\text { Moment of inertia } \\
\text { symbol }(I)\end{array}$ & $\begin{array}{l}\text { A geometrical property of a beam or member. Moment of Inertia, (also called second moment of area) reflects the } \\
\text { cross-sectional size and shape of a beam. It must be specified with respect to a selected axis (see Figure 6). }\end{array}$ \\
\hline $\begin{array}{l}\text { Moment of inertia } \\
\text { (circle); } I_{\text {Circle }}\end{array}$ & $0.25 \pi \mathrm{r}^{4}$ for bending if the member is circular. \\
\hline $\begin{array}{l}\text { Moment of inertia } \\
\text { (ellipse); } I_{\text {Ellipse }}\end{array}$ & $0.25 \pi r y^{3} r_{x}$ for bending about the $x$-axis if the member is elliptical. \\
\hline $\begin{array}{l}\text { Shear strain } \\
\text { symbol }(\gamma)\end{array}$ & Change in angle between two line segments that were originally perpendicular. \\
\hline $\begin{array}{l}\text { Strain } \\
\text { symbol }\left(\varepsilon_{\text {normal }}\right)\end{array}$ & $\begin{array}{l}\text { Change in length divided by original length, expressed as a percentage or fraction. Strain can be: } \\
\text { positive - elongation under tension, or } \\
\text { negative - contraction under compression. }\end{array}$ \\
\hline Strength & A measure of the ultimate stress in a member, often measured at the point of failure. \\
\hline $\begin{array}{l}\text { Stress } \\
\text { symbol }(\sigma)\end{array}$ & $\begin{array}{l}\text { A measurement of force per unit area } \\
\sigma=\mathrm{F} / \mathrm{A}\end{array}$ \\
\hline $\begin{array}{l}\text { Axial stress } \\
\text { symbol }\left(\sigma_{\text {Axial }}\right)\end{array}$ & Stress created during axial loading. \\
\hline $\begin{array}{l}\text { Bending stress } \\
\text { symbol }\left(\sigma_{\text {Bend }}\right)\end{array}$ & Stress created during bending. \\
\hline $\begin{array}{l}\text { Torsional stress } \\
\text { symbol }(\tau)\end{array}$ & Stress created during a twist. \\
\hline
\end{tabular}

Gelder et al. 2006; Anten and Schieving 2010; Niklas and Spatz 2010; Onoda et al. 2010). Specific gravity (SG) is the density of a material relative to the density of water and is often considered as a surrogate measure for wood properties, including $E$ and $M O R$ (Williamson and Wiemann 2010; Spatz and Pfisterer 2013). Use of $\mathrm{SG}$ as a surrogate measure, however, must be considered carefully to avoid introducing error (Williamson and Wiemann 2010).

The literature describing wood properties is extensive, reflected in numerous textbooks, some of which have multiple editions (Panshin and De Zeeuw 1980; Haygreen and Bowyer 1982; Kollman and Cote 1984; Bodig and Jayne 1993). Most of this work, however, was undertaken on clear, defectfree specimens to understand wood properties of lumber used in engineered structures. Reference books provide mean values of wood properties for many species (Jessome 1977; Lavers 1983; Wessolly and Erb 1998; Kretschmann 2010). Applying these values to living trees presents challenges because of the inherent variability due to a wide range of natural and anthropogenic causes (Zobel and van Buijtenen 1989). Even using material properties of branches and trunks of urban trees, as Lundström et al. (2007) suggest, presents problems. Branches and trunks failed at smaller values of MOR measured on specimens taken from the branches (Kane 2007) or trunks (Kane and Clouston 2008). 
Material properties of wood vary with age, growing conditions, genetics, moisture content (MC), and location in an individual (Figure 2). For example, variation in mean values of $E$ and MOR ranges from $16 \%$ to $60 \%$ (Clair et al. 2003; Woodrum et al. 2003; Dahle and Grabosky 2010b; Kretschmann 2010). Wood properties measured on "dry" specimens [i.e., moisture content less than fiber saturation point (FSP)-between $30 \%$ and $35 \%$ ] are typically greater (Figure 2) than when measured on "green" wood (i.e., MC > FSP) (Cousins 1976; Cousins 1978; Cannell and Morgan 1987; Kane 2007; Kane and Clouston 2008; Kane 2014).

Values of $E$ and $M O R$ are not uniform within an individual tree. Small specimens are taken from a trees to determine material property values and these specimens are typically (i) defectfree and straight-grained, and (ii) sampled from near the base of the trunk (ASTM 2014). Assuming such values apply to wood higher along the trunk or branches is problematic because $E$ and $M O R$ decrease axially with trunk height (Milne and Blackburn 1989; Yoshida et al. 1992; Niklas 1997a; Niklas 1997b; NIklas 1997c; Brüchert et al. 2000; Rowe and Speck 2005; Spatz et al. 2007; Lundström et al. 2008; Speck and Burgert 2011) and branch length (Cannell and Morgan 1987; Dahle and Grabosky 2010b). E also increased branch nodes to help bear loads in twigs (Caringella et al. 2014).

Wood properties are also influenced by cambial age, and hence, radial position in the cross section (Figure 3). On smaller branches, the greater proportion of juvenile wood can also influence $E$ and $M O R$. The effect of juvenile wood may not apply to large branches, except in the case of topped or pollarded trees, which often produce large watersprouts with a large proportion of juvenile wood (Dahle et al. 2006). Juvenile wood is located near the pith and is produced early in the life of a trunk or branch, but the transition to mature wood is usually gradual, occurring over several years. The cells tend to be shorter with thinner cell walls than in mature wood (Read and Stokes 2006). Juvenile wood typically has lower values of $E$ and $M O R$ than mature wood (Lindström et al. 1998; Lichtenegger et al. 1999; Evans et al. 2000; Pruyn et al. 2000; Plomion et al. 2001; Thibaut et al. 2001; Groom et al. 2002a; Groom et al. 2002b; Mott et al. 2002; Woodcock and Shier 2002; Woodrum et al. 2003; Pilate et al. 2004; Kern et al. 2005; Read and Stokes 2006; Dahle and Grabosky 2010b). E was found to be up to $75 \%$ greater in mature wood than in juvenile wood of Acer platanoides (Dahle and Grabosky 2010b). This makes sense, as more flexible distal tree parts facilitate crown reconfiguration in the wind, increasing safety factors of smaller trees (Niklas 2002), and more rigid proximal tree parts resist self-weight and wind-induced bending and torsional moments (Dahle and Grabosky 2010 b). As wood matures, the radial variation in $E$ decreases in both trunks (Clair et al. 2003) and branches (Dahle and Grabosky 2010b).

Values of $E$ and MOR for ornamental or introduced species are not always included in references (Jessome 1977; Lavers 1983; Wessolly and Erb 1998; Kretschmann 2010). Assuming values of wood properties from other regions may be problematic, given the effect of growing conditions on wood properties. Wood properties can also vary between cultivars and hybrids (Pruyn et al. 2000; Kern et al. 2005), which are not usually included in references (Jessome 1977; Lavers 1983; Wessolly and Erb 1998; Kretschmann 2010). Some work has modeled $E$ and $M O R$ in trunks (Lundström et al. 2008) and branches (Dahle and Grabosky 2010b), but very little work has considered the values for root wood (Coutts 1983; Pratt et al. 2007) and woundwood (Kane and Ryan 2003).

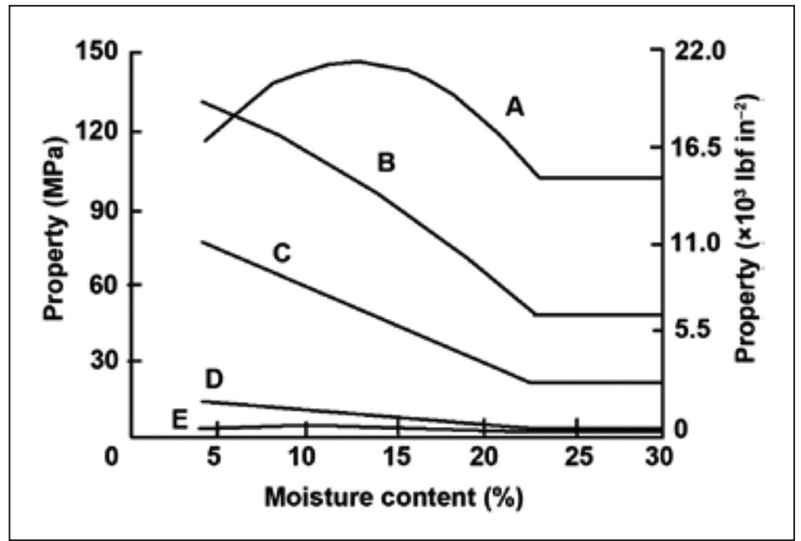

Figure 2. Effect of moisture content on wood strength properties. A, tension parallel to grain; B, bending; C, compression parallel to grain; D, compression perpendicular to grain; and E, tension perpendicular to grain. Courtesy of Kretchmann (2010). 


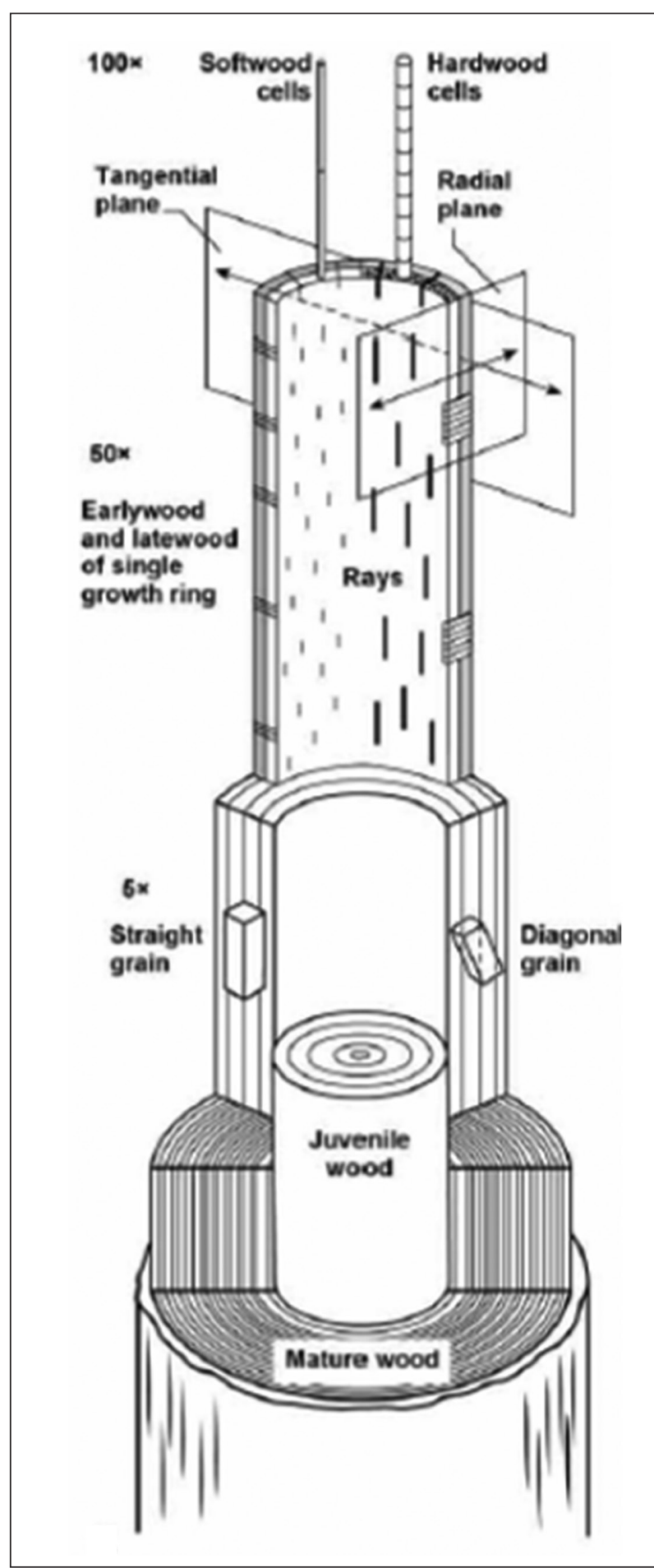

Figure 3. Depiction of a tree stem or branch, denoting the location of juvenile and mature wood. Courtesy of Wiedenhoeft (2010).

In summary, the two most commonly reported material properties in the tree biomechanics literature ( $E$ and $M O R)$ are integral to understanding the static load-bearing capacity of trees. They are positively correlated with wood density and SG, and increase as MC decreases below FSP. In mature wood, $E$ and $M O R$ tend to be greater than in juvenile wood, which allows distal branch tips to bend more freely, while the stiffer and stronger wood at the base of trunks and branches provides the necessary structural support.

\section{TREE FORM}

The static load-bearing capacity of trees is also governed by their form-specifically, the length and diameter of the trunk and branches and the direction of loading (Figure 4). Length of trunks and branches affects the bending and torsional moments (also known as "torques") induced by loads. When subjected to the same load, longer branches and trunks endure greater torques than shorter ones. The load-bearing capacity of trunks and branches is related to their crosssectional area and second moment of area, which is also known as the moment of inertia (or simply " $I$ "). The effect of diameter on the load-bearing capacity of trunks and branches is non-linear: cross-sectional area and $I$ are proportional to the square and fourth power, respectively, of diameter.

Since $I$ is proportional to the fourth power of diameter, material farthest from the centroid of a cross-sectional area contributes disproportionately to $I$. Most of the "flexural stiffness" (the product of $E$ and $I$, see Table 1) of a trunk or branch is conferred by the outer growth rings, even though it represents only a small proportion of trunk diameter (Mencuccini et al. 1997; Niklas 1997a; Niklas 1997b). Flexural stiffness, which affects deformation and deflection in a branch or trunk, may be most efficiently increased through increases in diameter, even if the wood is less stiff (Lavandjara and Müller-Lanndau 2010).

Investigators often consider the ratio of length to diameter, which is known as the slenderness (length/diameter) of a trunk or branch, and is considered to be a good predictor of stability (Rosłon-Szeryńska and Kosmala 2007). Foresters use slenderness to assess stability of residual trees after harvesting a stand. Slenderness values below 100 are typically considered stable for gymnosperm trees (Petty and Worrel 1981; Cremer et al. 1982; Petty and Swain 1985; Wang et al. 1998). Slenderness may be tied to life history. 
Shaded trees often have high slenderness values (Osunkoya et al. 2007; Mattson and Putz 2008; Harja et al. 2012) as they grow to obtain more light, (Jaouen et al. 2010). In contrast, the slenderness of self-supporting Tachigali melinonii and Dicorynia guianensis trees did not exceed 100, even when staked (Jaouen et al. 2010).

Branch slenderness may also change over time (McMahon and Kronauer 1976; Bertram 1989; Dahle and Grabosky 2010a), approaching 100-125 in young branches that function as solar collectors (Bertram 1989; Dahle and Grabosky 2010a). Slenderness of mature branches, which are primarily structural, decreases when a branch reaches around three meters in length (Figure 5) (Dahle and Grabosky 2010a). Changes in slenderness are governed by a decrease in

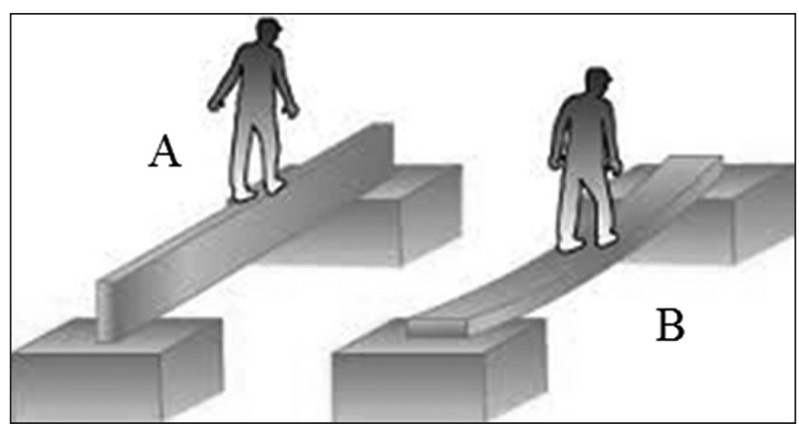

Figure 4. The orientation of a beam influences the resistance to the applied load. Both beams are the same size and subjected to the same loading. The vertically oriented beam (A) has a higher moment of inertia ( $I$ ) parallel to the direction of loading and thus resists bending better than the horizontally loaded beam (B).

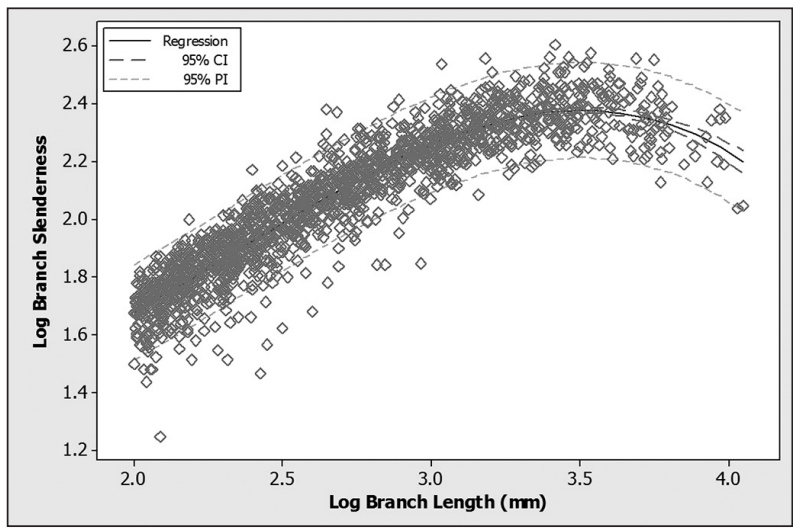

Figure 5. Branch slenderness (length / diameter) increases with length until around 3,000 millimeters. At which point slenderness begins to decrease as the branch transitions from a solar role to a structural role, where the moment of inertia ( $($ ) becomes more important. Courtesy of Dahle and Grabosky (2010a). annual elongation and perhaps an increase in diameter growth. Such changes are important in the survival of neo-tropical rainforest saplings (Coutand et al. 2010) and young Acer platanoides branches (Dahle and Grabosky 2010a).

\section{Allometry}

Allometry has also been used to explore the relationship between length and diameter of trunks and branches. An early attempt came from Greenhill (1881), who investigated the critical buckling height of a tree, considered as a column, using the following formula:

$$
H_{\text {critical }}=C\left(\frac{E}{\rho}\right)^{\frac{1}{3}} r_{s}^{\frac{2}{3}}
$$

where $H_{\text {critical }}=$ critical height, $\mathrm{C}=\mathrm{a}$ proportionality constant $(1.26$ for cylinders and 1.96 for tapered cones), $\rho=$ wood density, and $r_{s}=$ radius of the column at its base.

Expanding this work, McMahon (1975) proposed three allometric models to describe the relationship between length (l) and radius (r) of a trunk or branch. In the elastic similarity model, $1 \propto \mathrm{r}^{2 / 3}$; in the geometric similarity model, $1 \propto \mathrm{r}^{1}$; and in the static stress similarity model, $1 \propto \mathrm{r}^{1 / 2}$. Since Dahle and Grabosky (2009) reviewed these "power law" models, researchers limit the current discussion in this review. While no model has been found to fit all trees, a general pattern appears in the literature. The geometric similarity model applies to gymnosperms and understory trees in rainforests (Niklas 1994a; Osunkoya et al. 2007), the static stress model applies to mature pines (Dean and Long 1986; Mäkelä 2002), and the elastic similarity model applies to many angiosperms (King 1986; Rich et al. 1986; Niklas 1994b; O’Brien et al. 1995; King 1996).

Allometry changes over time, and trees might transition through two or all three of the power law models (Niklas 1994a; Niklas 1995; Osunkoya et al. 2007). The transition is due to a mechanical signal (Jaffe 1976; Telewski and Jaffe 1986a; Telewski and Jaffe 1986b; Braam and Davis 1990; Braam 2005; Telewski 2006; Coutand et al. 2008; Chehab et al. 2009; Coutand et al. 2010), such as the amount of longitudinal strain in Prunus avium saplings (Coutand et al. 2008) induced by a mechanical 
perturbation (Pruyn et al. 2000; Rowe and Speck 2005; King et al. 2009) that triggers a genetic or hormonal response. For example, an increase in low frequency loading was found to increase diameter growth in Pinus taeda (Telewski 1990) and Prunus avium (Coutand et al. 2008), and ethylene production is increased with loading (Telewski 1990; Telewski and Pruyn 1998). Researchers caution that while loading alters growth, little is known on what a typical daily loading regime might look like (Coutand et al. 2010), and therefore the extent of the induced growth response.

There are a number of signals to mechanical perturbation that trigger physiological responses [see Braam (2005) and Chehab et al. (2009) for reviews], yet the principal controller remains elusive. Research suggests that there may be a control at the genetic level (Rowe and Speck 2005), especially with $\mathrm{TCH}$ or touch genes (Braam 2005) that have been identified in thigmomorphogenetic responses (Braam 2005; Telewski 2006; Chehab et al. 2009; Coutand et al. 2010).

\section{Modeling Growth}

Mechanical stimuli can influence growth (Coutand et al. 2008), and the resulting allometric shifts as trees grow may limit computer models to predict tree growth. Growth models take different approaches, including the pipe model (Berninger and Nikinmaa 1997; Chiba 1998; Mäkelä 2002), fractals (Lindenmayer 1968; Berezovskava et al. 1997), power laws (Dean and Long 1986; King 1986; Rich et al. 1986; Niklas 1994b; O’Brien et al. 1995; Spatz and Brüchert 2000; Sposito and Santos 2001; Mäkelä 2002), or a combination of fractals and power laws (Pluciński et al. 2008), but all have important limitations. For example, many models assume plagiotropic growth, which is appropriate for young gymnosperms (Lindenmayer 1968; Berezovskava et al. 1997; Suzuki and Suzuki 2009), but may be inappropriate for mature conifers or many angiosperms that exhibit orthotropic growth. Neither have models explicitly considered for urban trees, which are of greatest interest to arborists.

Arborists must understand slenderness and allometry of trunks and branches to understand their load-bearing capacity. Non-linear relationships between diameter and load-bearing capacity show its relative importance compared to material proper- ties. Allometry has been shown to change as trunks and branches become larger. Decreases in slenderness appear to be associated with a reduction in elongation, as the trunk or branch assumes primarily a structural rather than a light-gathering role.

\section{DECAY AND STRENGTH LOSS}

There are numerous defects that elevate the likelihood of tree failures, such as cavities, included bark, weak branch unions and codominant branches, cracks, splits, and decay (Dahle et al. 2014). While all of these are important, decay has received considerable attention in the literature. Decay is a natural process in which fungi decompose wood (Schwarze et al. 1997; Schwarze et al. 2000) and the loss of wood reduces the load-bearing capacity of a trunk or branch. The biomechanical relevance of decay in trees is important in tree risk assessment. Decay is often cited as a structural defect warranting tree removal (Terho and Hallaksela 2005) and even incipient decay can result in significant decreases in wood properties without significant loss of wood weight (Wilcox 1978; Zabel and Morrell 1992).

As bending stress is greater on the perimeter, the presence of decay does not necessarily indicate or elevate the likelihood of failure. For many years, a starting point to assess whether decay had significantly increased the likelihood of failure was based on Wagener's (1963) observation that conifers growing in the USA's Pacific Northwest region were more likely to fail when the trunk was $70 \%$ decayed (or hollow). Wagener (1963) cautioned that his observations should not be extrapolated to other areas or species, but his findings were largely supported by observations of failed and standing trees after a hurricane in North Carolina, USA (Smiley and Fraedrich 1992). Wagener (1963) developed the guideline with a formula into which practitioners could enter the diameter of a decayed (or hollow) cross section $\left(\mathrm{d}_{\mathrm{i}}\right)$ and the trunk diameter at the point of decay $\left(\mathrm{d}_{\mathrm{o}}\right)$ :

[2] $\quad d_{i}^{3} / d_{0}^{3}$ (Wagener 1963)

Coder (1989) proposed a similar method of assessing the likelihood of failure of trunks with decay:

[3] $\quad d_{i}^{4} / d_{o}^{4}$ 
Recent work on small conifers questioned the reliability of predicting the effect of decay on trunk strength (Ruel et al. 2010), but the sample was limited to very few trees with more than $50 \%$ decay. Equations 2 and 3 show that loss in $I$ of these trunks would be relatively small, unless the decay were off center or non-circular. When areas of decay are not concentric, Equations 2 and 3 become less accurate (Kane and Ryan 2004). Smiley and Fraedrich (1992) modified Equation 2 to account for cavities in the trunk; their modification reasonably predicted strength loss due to offset decay (Kane and Ryan 2004). Mattheck et al. (1993) developed a formula to predict failure from a similar criterion based only on the ratio of sound wood thickness $(t)$ and trunk radius (R). As originally presented, their data appeared to show a clear demarcation between standing and failed trees in the low diameter range when $t / R>0.30-0.32$ (Mattheck et al. 1993; Mattheck et al. 1994; Mattheck and Bethge 2000). With respect to predicting strength loss, this formula also reasonably accounted for offset decay (Kane and Ryan 2004), but the validity of the interpretation of the data has been called into question (Gruber 2008; Schwarze 2008). The value of strength loss at which Wagener (1963) and Smiley and Fraedrich (1992) suggested trees had a greater likelihood of failure was 33\%, analogous to Mattheck et al.s (1993) suggestion. Kane (2014) cut hollows into trees and found evidence to support this convention.

Calculations of $I$ are based entirely on geometry, and the formulae reported above assume that crosssectional areas are circular. For small deviations from a circular area, this assumption would not introduce meaningful error. As areas become more elliptical, however, simply adjusting Equations 2 and 3 to consider elliptical areas is problematic. For an asymmetrical area of decay, Mattheck et al. (1993) conservatively assumed that the area was inscribed in a circle, the radius of which was used to determine t/R. Koizumi and Hirai (2006) numerically calculated section modulus of irregular-shaped decay cross sections using high-resolution images. Ciftci et al. (2014) used a conservative approach to assess strength loss due to irregularly shaped areas of decay.

The adoption of advanced technological methods of measuring decay or determining strength promises to improve the understanding the likelihood of failure due to decay. The effectiveness of technologically advanced decay-detecting devices is still unclear (Nicolotti et al. 2003; Gilbert and Smiley 2004; Deflorio et al. 2008; Wang and Allison 2008; Butnor et al. 2009; Seifert et al. 2010). Improving the accuracy of such devices, as well as the images they produce, would facilitate the numerical evaluation of decayed cross sections.

Although considerable scholarly effort has been expended on evaluating decay-detecting devices [see Johnstone et al. (2010) for a review], the effect of decay on tree failure has been studied much less. Few studies have quantified the effect of decay on the likelihood of trunk (Kane 2014) and branch (Dahle et al. 2006) failure. And while many studies investigating parameters related to the failure of urban trees following windstorms [see Duryea et al. (2007) for a review], far fewer have examined the effect of decay. Gibbs and Greig (1990) found that $32 \%$ of failures were associated with decay, but the effect of decay varied among species. In contrast, Kane (2008) observed far fewer failures associated with decay, which was due to the preponderance of uprooted trees. Decay presumably influences the likelihood of branch failure during ice accretion (Hauer et al. 2006), but Equations 2 and 3 indicate that decay must be substantial or eccentric to reduce the load-bearing capacity of a trunk or branch. This is why Kane and Finn (2014) found little evidence that defects increased the likelihood of failure of trees loaded by snow.

Degradation of wood due to decay reduces the load-bearing capacity of a tree, and guidelines to assess the effect of the amount of decay exist. Many studies have focused on the performance of decay-detecting devices, which are often used to assess the extent of decay in a trunk, branch, or root. When assessing the likelihood of failure, however, qualified arborists assess more than just the location and amount of decay. Whether a threshold amount of decay or a reduction in a factor of safety exists for particular species or loading conditions remains an important research question.

\section{STATIC LOAD TEST OF URBAN TREES}

Static load tests on trees use a rope or cable attached to the tree to apply a controlled static load to test the strength of the trunk and to estimate the stability of the tree in the ground (Sinn and Wessolly 1989; 
Wessolly 1991; Brudi and van Wassenaer 2001; van Wassenaer and Richardson 2009). Static load tests can be used to assess maximum loads at failure in the trunk or root plate by testing to destruction (Peltola 2006; Lundstrom et al. 2007), or can be used to induce non-destructive bending stress $(\sigma)$ in the trunk in the linear elastic range. During these tests, axial trunk strains $(\varepsilon)$ are measured on the marginal fibers of the trunk, and Hooke's Law

\section{[4] $\quad E=\sigma / \mathcal{E}$}

is used to extrapolate the critical bending moment of the defective trunk from a guideline value for critical fiber compression (Wessolly 1991; Brudi and van Wassenaer 2001). Clair et al. (2003) stated that wood follows approximately a simple one-dimension Hooke's Law in the longitudinal direction. Critical compression often is determined from previous laboratory tests on wood specimens or assumed from the literature (Jessome 1977; Lavers 1983; Brudi and van Wassenaer 2001; Spatz and Pfisterer 2013), which can confound the analysis. As material properties vary with wood density (Niklas and Spatz 2010), their correlation is believed to remain constant (Brudi and van Wassenaer 2001; Wessolly and Erb 1998). This method may be useful, but the tests made in the elastic range of the wood (i.e., linear and recoverable strains) only allow for predictions of the proportional limit of the stress-strain curve. This point of primary failure serves as a criterion for the safety of urban trees (Detter et al. 2015) despite the fact that presumed plastic strains may occur and increase the bearing capacity of living trees. The ultimate strength of tree trunks may be estimated from the proportional limit, but with limited reliability (Pfisterer and Spatz 2012; Detter et al. 2014).

The static load test (Wessolly 1991) provides a quantitative approach for non-destructively assessing the uprooting resistance of intact or compromised root systems of standing trees. During the test, the root-plate rigidity is measured because it has also been identified as a good indicator for anchorage strength (Ray and Nicoll 1998; Ghani et al. 2009). A close correlation between bending moments required to induce small changes in soil-root-plate inclinations and the maximum resistive moment of the root system generated during the uprooting process has been established for several species (Vanomsen 2006; Smiley 2008; Lundström et al. 2009) and was used to extrapolate failure loads (Lundström et al. 2009; Sani et al. 2012; Smiley et al. 2014). The generalized tipping curve postulated by Wessolly $(1994 ; 1996)$ has been criticized (Vanomsen 2006), but a similarity in tipping behavior across species with a maximum resistive moment of the anchorage at low angles between two degrees and six degrees has been reported from many studies (Coutts 1986; England et al. 2000; Vanomsen 2006; Lundström et al. 2007). The angle of root-plate rotation at maximum resistance is greater for young trees (Crook and Ennos 1996; Stokes 1999), and likely varies with tree age class (Stokes 1999; Yang et al. 2014). Root architecture (Mickovski and Ennos 2003; Dupuy et al. 2007), and soil structure (Ray and Nicoll 1998; Rahardjo et al. 2013, which are important components to the resistance to uprooting.

The load to cause failure may be lower when a cavity (hollow) extends more than one-third of the axial length of the trunk (Spatz and Niklas 2013). Spatz et al. (1997) suggested that both tangential and longitudinal $E$ may be important when modeling hollow plant trunks. Their work considered the giant reed (Arundo donax) (Spatz et al. 1997), but the findings transfer to trees with hollow trunks with regard to transverse stresses (Spatz and Speck 1994) and local buckling.

Static load tests have been coupled with fullscale, optical 3D digital image correlation (DIC) measurements of deformations and strains on the surface of branches, trunks, and roots. DIC promises to further study the biomechanics of bending, torsion, and fracture in woody plants. The first results of studies related to urban trees have been published recently [Sebera et al. 2014; Löchteken and Rust 2015; Hesse et al. 2016; Sebera et al. 2016; Dahle (in review)].

Much of the work on static load tests has concentrated on the relationship between stress and strain within the proportional limit. While this may be useful when studying primary failure of a tree trunk, researchers should also consider the impact of plastic strains in terms of the loadcarrying capacity of urban trees. The adoption of DIC measurements may allow a more in-depth understanding of strains during static load trials. 


\section{ROOT FAILURES}

As trees grow in size, their root system develops greater strength (Crook and Ennos 1998; Mickovski and Ennos 2003). The ability to support trees depends on root spread (Mergen 1954; Nicoll and Ray 1996; Tobin et al. 2007), root architecture (Coutts et al. 1999; Dupuy et al. 2005; Ji et al. 2007; Khuder et al. 2007; Gilman and Masters 2010; Krause et al. 2014), soil type (Mattheck et al. 1997; Moore 2000; Dupuy et al. 2005; Ji et al. 2007; Ow et al. 2010), and root-plate development (Dupuy et al. 2005; Fourcaud et al. 2008; Lundström et al. 2009; Dupuy et al. 2007; Ghani et al. 2009). While soil conditions (type, texture, and moisture content) are important factors (Day et al. 2010) in root/tree stability, this review is concentrating on the root system's influence on tree stability.

Several models for the mechanics of uprooting are proposed from experimental studies (e.g., Coutts 1986; Wessolly 1996; Ennos 2000). Model simulations have investigated the mechanics of anchorage and uprooting (Dupuy et al. 2007; Rahardjo et al. 2013; Yang et al. 2014). During the uprooting process, the pivot point shifts from the trunk axis to a hinge point on the leeward side of the trunk directly outside the trunk-root joint (Coutts 1986; Ennos 2000) where the greatest strains were measured for buttressed trees (Crook et al. 1997) and young trees with tap roots (Stokes 1999). Compression failure can be found after uprooting in this region as well (Mergen 1954; Coutts 1986).

The most important region appears to be the soil-root plate (Dupuy et al. 2005; Ji et al. 2007; Tobin et al. 2007; Ghani et al. 2009). The soil-root plate includes the first-order roots in the zone of rapid taper, and the soil in which these roots grow, and resists the turning moment and holds a tree in the ground. Ghani et al. (2009) found that turning moment in Eugenia grandis was affected by trenching at 0.5-1.0 $\mathrm{m}$, and root depth was the major factor for undamaged trees or if roots were trenched at $1.5 \mathrm{~m}$ distance. The depth of the soil-root plate appears to be an important factor in stability (Mickovski and Ennos 2003; Nicoll et al. 2006a; Fourcaud et al. 2008; Ghani et al. 2009), especially in sandy (Dupuy et al. 2005; Ji et al. 2007) or clayey soils (Dupuy et al. 2005).
Using FEM analysis, Ji et al. (2007) reported that lateral roots provided $30 \%$ of total anchorage strength in clay soils. The distribution of forces among lateral roots was found to be unequal, with a ratio between 1:2 and 1:3 between leeward and windward Pinus radiata roots (Watson 2000), but the author cautioned that measurements on the leeward side were undertaken outside the effective roots zone. Smiley (2008) reported that anchorage strength of Platanus $\times$ acerifolia changed more than $15 \%$ if the root plate was trenched at a distance less than twice the trunk diameter, and roughly $35 \%$ if lateral roots were severed at the trunk base. During subsequent tests, the side where roots were cut only had an influence when soil was water saturated, but not under dry conditions (E.T. Smiley pers. comm.), again demonstrating the importance of soil condition in tree stability.

Urban trees do not have strong central vertical roots (Nielsen 2010). Tap roots, when present, may add some structural support (Mickovski and Ennos 2003; Fourcaud et al. 2008) especially in juvenile trees until lateral roots develop (Burdett et al. 1986; South el al. 2001; Khuder et al. 2007). While the geometry of the root system changes over time, the basic geometry of the root plate is laid down early and remains unchanged (Coutts and Lewis 1983; Khuder et al. 2007) in trees growing naturally. Watson and Tombleson (2002) suggested that an early indicator of tree stability is the increase in biomass of lateral roots near the trunk in seedlings. Coutts and Lewis (1983) report that in Picea sitchensis, structural roots are laid down early. It is likely that root pruning, whether in the nursery or post-transplanting, may alter long-term stability (Gilman and Masters 2010).

Picea glauca roots appear to respond to loading regimes quicker than trunks (Urban et al. 1994). When trees are inclined to a greater degree (above 1-2.5 degrees) at the trunk base, they do not return to their upright position (Sinn 1990) and the stiffness of the root-soil plate is decreased (Lundström et al. 2009). The same result can be achieved by cyclic loading beyond one degree inclination (Rogers et al. 1995; Vanomsen 2006). In a reaction to high loading, root shape can be altered by loading (Stokes et al. 1998; Stokes 1999), and adaptive growth of roots decreases the likelihood of overturning after a 
loading event (Stokes 1999; Berthier and Stokes 2006; Khuder et al. 2007). When growing on the uphill side of a slope, more first-order Picea sitchensis lateral roots were found (Nicoll et al. 2006b), and roots can have thicker-walled fibers and small diameter vessels that increase mechanical support (De Micco and Aronne 2010). It is possible that a rapid screening tool could be developed to use root system plasticity as selection criteria for more mechanically stable trees.

During static load tests of Picea abies, Abies alba, and Pinus sylvestris, Lundström et al. (2007) found that $75 \%$ of the variation of the turning moment in the soil-root plate was explained by tree mass, trunk mass, trunk diameter, or tree height, either alone or in combination. The critical turning moment in a number of conifers throughout Great Britain increased by $10 \%-15 \%$ when roots were able to penetrate the soil deeper than $80 \mathrm{~cm}$ (Nicoll et al. 2006a). A negative linear relationship was found between the force to cause a tilt and the distance of root severance as multiples of trunk diameter (Smiley 2008) as well as the percentage of Acer rubrum roots severed (Smiley et al. 2014), suggesting that models can be built to predict tree instability due to trenching.

While roots play an important role in terms of anchoring the tree into the ground, the importance of soil cannot be neglected. Soil can only stretch by less than $2 \%$ while roots can stretch $10 \%-20 \%$ (Tobin et al. 2007), especially when less than 2 $\mathrm{mm}$ in diameter (Mattia et al. 2005). Fine roots act to hold the soil together, which helps define the dimension of the soil-root plate (Tobin et al. 2007). The fine roots play a role in physical support as they help hold the soil in place (Genet et al. 2005), which may be important when the soil is saturated and under high wind conditions (Figure 6). Tobin et al. (2007) suggested that models of overturning of shallow root systems should include four mechanical components: 1) weight of soil-root plate, 2) tensile strength of windward roots, 3) tensile strength of soil, and 4) resistance to bending of roots at the hinge point (Coutts 1986; Blackwell et al. 1990). The water content, as well as the location of water in the root-soil plate play important roles in the resistance to uprooting in storms (Kamimura et al. 2011).

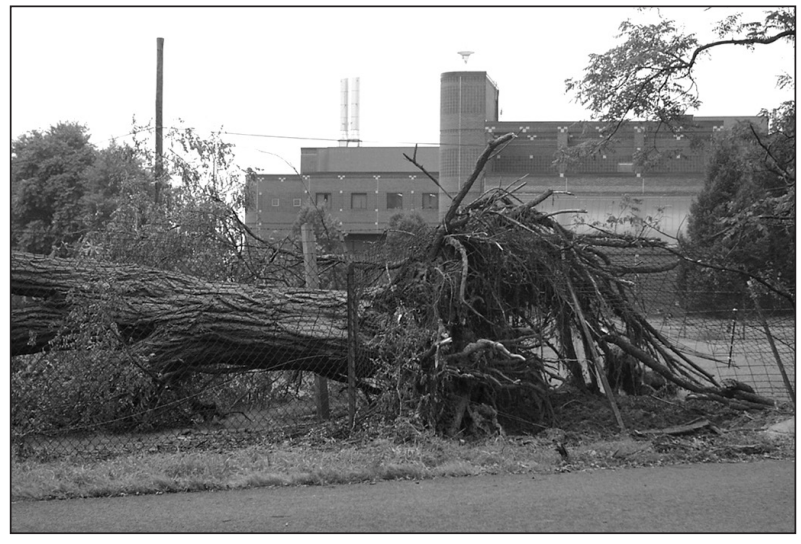

Figure 6. Tree failure resulting from saturated soil conditions during tropical storm Ernesto, in 2006.

The soil-root plate is an important area of future study because root failures are common in amenity trees. Data from the International Tree Failure Database (ITFD) indicate that root failures make up $35.6 \%$ of total tree failures (ITFD 2014). Models to predict the resistive moment of the soil-root plate of forest- or plantation-grown trees can offer insights into the behavior of amenity trees. Root architecture varies according to age, species, and growing conditions, so models may not apply over the range of variability in these parameters. In particular, belowground growing conditions in urban areas are distinctly different from those in which most previous work has occurred. The texture and volume of soil available to amenity trees in urban areas often precludes ready application of prediction models derived from forest- or plantation-grown trees. Whether belowground space in urban areas can be designed to enhance the resistive moment provided by the soil-root plate is a compelling question. The frequency with which tree roots are damaged in urban areas adds another level of complexity in predicting the resistive moment that the soil-root plate provides-this is another important area for future study. Since nursery production methods can influence the geometry of early root plate formation, there is a need to continue efforts in developing an understanding of what might be considered a normal root architecture to then appraise root system quality. 


\section{CONCLUSION}

In the last twenty years, arboricultural researchers have attempted to better understand how trees withstand loading, largely in the context of assessing the likelihood of tree failure. Tree form and the material properties of wood determine the load-bearing capacity of a tree. Material properties, like $E$ and $M O R$, vary ontogenetically and by species and growing conditions. Although many references include wood properties, most of the work comes from specimens taken from forest- or plantation-grown trees, and defect-free specimens of lumber. Applying these values to living branches, trunks, and roots of open-grown trees in urban areas should be done with care. More work on living trees is needed to obtain accurate material properties for individual trees and allow for variations in species and location. Variability in $E$ and $M O R$ influences the load-bearing capacity of trees, but the effect of tree form often supersedes that of $E$ and $M O R$, because changes in diameter have a curvilinear influence on $I$ of a branch, trunk, or root. For branches and trunks, diameter and length often follow predictable proportionalities, but very little of the empirical work has been conducted on amenity trees in urban areas. More data describing the allometry of the branches, trunks, and roots of amenity trees in urban areas are critical to better understanding their load-bearing capacity. Additional research is needed to better understand where maximum loading occurs on a trunk or branch in order to predict where failure is most likely to occur.

A commonly assessed structural defect in trees, decay reduces the load-bearing capacity of branches, trunks, and roots, and determining threshold extents of decay is a useful line of investigation. Advanced techniques to assess the effect of decay such as static pulling tests provide a baseline of assessment, but need additional refinement and validation. Static load tests are also used to assess belowground stability since the soil-root plate is integral to anchoring trees and providing a resistive moment against loading. Exploring the root architecture of amenity trees growing in urban areas to determine whether existing models can predict the resistive moment provided by the soil-root plate of amenity trees is another important area for future study.
Sophisticated measuring devices and analytical techniques (e.g., DIC and FEM) hold great promise to improve the study and practice of assessing the load-bearing capacity of trees. The complicated structure of most amenity trees growing in urban areas still presents many challengesin both research and practice-to overcome.

Acknowledgments. We thank the International Society of Arboriculture and its Science and Research Committee for funding this literature review and USDA McIntire-Stennis funds (WVA00108). Iwona Cynk-Dahle and several anonymous reviewers provided valuable suggestions to improve earlier drafts of this manuscript.

\section{LITERATURE CITED}

Alméras, T., J. Gril, and E. Costes. 2002. Bending of apricot tree branches under the weight of axillary growth: test of a mechanical model with experimental data. Trees 16:5-15.

Anten, N.P.R., and F. Schieving. 2010. The role of wood mass density and mechanics constrains in the economy of tree architecture. American Naturalist 175:250-260.

ASTM. 2014. Standard Test Methods for Small Clear Specimens of Timber. D143-14.

Berezovskava, F.S., G.P. Karev, O.S. Kisliuk, R.G. Khlebopros, and Y.L. Tsel'niker. 1997. A fractal approach to computer-analytical modeling of tree crowns. Trees 11:323-327.

Berninger, F., and E. Nikinmaa. 1997. Implications of varying pipe model relationships on Scots pine growth in different climates. Functional Ecology 11:146-156.

Berthier, S., and A. Stokes. 2006, Righting response of artificially inclined maritime pine (Pinus pinaster) saplings to wind loading. Tree Physiology 26:73-79.

Bertram, J.E.A. 1989. Size-dependent differential scaling in branches: The mechanical design of trees revisited. Trees 4:241-253.

Blackwell, P.G., K. Rennolls, and M.P. Coutts. 1990. A root anchorage model for shallowly rooted Sitka spruce. Forestry 63:73-91.

Bodig, J., and B.A. Jayne. 1982. Mechanics of Wood and Wood Composites. Van Nostrand Reinhold Company, New York, U.S.

Braam, J. 2005. In touch: Plant responses to mechanical stimuli. New Phytologist 165:373-389.

Braam J., and R.W. Davis. 1990. Rain-, wind-, and touch-induced expression of calmodulin and calmodulin-related genes in Arabidopsis. Cell 60:357-364.

Brüchert, F., F. Becker, and T. Speck. 2000. The mechanics of Norway spruce [Picea abies (L.) Karst]: Mechanical properties of standing trees from different thinning regimes. Forest Ecology and Management 135:45-62.

Brudi, E., and P. van Wassanaer. 2001. Trees and statics: Nondestructive failure analysis. pp. 53-69 In: E.T. Smiley, and K.D. Coder (Eds.). Tree Structure and Mechanics Conference Proceedings: How Trees Stand Up and Fall Down, International Society of Arboriculture, Champaign, Illinois, U.S. .

Burdett, A.N., H. Coates, R. Eremko, and P.A.F. Martin. 1986. Toppling in British Columbia's lodgepole pine plantations: Significance, cause, and prevention. Forestry Chronicle 62:433-439.

Burgert, I. 2006. Exploring the micromechanical design of plant cell walls. American Journal of Botany 93:1391-1401. 
Butnor, J.R., M.L. Pruyn, D.C. Shaw, M.E. Harmon, A.N. Mucciardi, and M.G. Ryan. 2009. Detecting defects in conifers with ground penetrating radar: Applications and challenges. Forest Pathology 39:309-322.

Cannell, M.G.R., and J. Morgan. 1987. Young's modulus of sections of living branches and tree trunks. Tree Physiology 3:355-364.

Caringella, M.A., B.A. Bergman, R.C. Stanfield, M.M. Ewers, E.G. Bobich, and F.W. Ewers. 2014. Effects of phyllotaxy on biomechanical properties of stems of Cercis occidentatlis (Fabaceae). American Journal of Botany 101:206-210.

Chehab, E.W., E. Eich, and J. Braam. 2009. Thigmomorphogenesis: A complex plant response to mechano-stimulation. Journal of Experimental Botany 60:43-56.

Chiba, Y. 1998. Architectural analysis of relationship between biomass and basal area based on pipe model theory. Ecological Modelling 108:219-225.

Ciftci, C., B. Kane, S. Brena, and S.R. Arwade. 2014. Loss in moment capacity of tree stems induced by decay. Trees 28:517-529.

Clair B., M. Fournier, M.F. Prevost, J. Beauchene, and S. Bardet. 2003. Biomechanics of buttressed trees: Bending strains and stresses. American Journal of Botany 90:1349-1356.

Coder, K.D. 1989. Should you or shouldn't you fill tree hollows? Grounds Maintenance 24:68-70.

Cousins, W.J. 1976. Elastic modulus of lignin as related to moisture content. Wood Science Technology 10:9-17.

Cousins, W.J. 1978. Young's modulus of hemicellulose as related to moisture content. Wood Science Technology 12:161-167.

Coutand, C., C. Dupraz, G. Jauoen, S. Ploquin, and B. Adam. 2008 Mechanical stimuli regulate the allocation of biomass in trees: Demonstration with young Prunus avium trees. Annals of Botany 101:1421-1432.

Coutand, C., M. Chevolot, A. Lacointe, N. Rowe, and I. Scotti. 2010. Mechanosensing of stem bending and its interspecific variability in five neotropical rainforest species. Annals of Botany 105:341-347.

Coutts, M.P. 1983. Development of the structural root system in Sitka spruce. Forestry 56:1-16.

Coutts, M.P. 1986. Component of tree stability Sitka spruce on peaty gley soil. Forestry 59:173-197.

Coutts, M.P., and G.J. Lewis. 1983. When is the structural root system determined in Sitka spruce? Plant Soil 71:155-160.

Coutts, M.P., C.C.N. Nielsen, and B.C. Nicoll. 1999. The development of symmetry, rigidity and anchorage in the structural root system of conifers. Plant and Soil 217:1-15.

Cremer, K.W., C.J. Borough, F.H. McKinnell, and P.R. Carter. 1982. Effects of stocking and thinning on wind damage in plantations. New Zealand Journal of Forestry Science 12:244-268.

Crook, M.J., and A.R. Ennos. 1996. The anchorage mechanics of deep rooted larch, Larix europea $\times$ L. japonica. Journal of Experimental Botany 47:1509-1517.

Crook, M.J., and A.R. Ennos. 1998. The increase in anchorage with tree size of the tropical tap rooted tree Mallotus wrayi, King (Euphorbiaceae). Annals of Botany 82:291-296.

Crook, M.J., A.R. Ennos, and J.R. Banks. 1997. The function of buttress roots: A comparative study of the anchorage systems of buttressed (Aglaia and Nephelium ramboutan species) and non-buttressed (Mallotus wrayi) tropical trees. Journal of Experimental Botany 48:1703-1716.
Dahle, G.A. (in review) Influence of Bark on the Measurement of Mechanical Strain using a Digital Image Correlation System. Wood Science and Technology.

Dahle, G.A., and J.C. Grabosky. 2009. Review of literature on the function and allometric relationships of tree stems and branches. Arboriculture \& Urban Forestry 35:311-320.

Dahle, G.A., and J.C. Grabosky. 2010a. Allometric patterns in Acer platanoides (Aceraceae) branches. Trees 24:321-326.

Dahle, G.A., and J.C. Grabosky. 2010b. Variation in modulus of elasticity (E) along Acer platanoides L. (Aceraceae) branches. Urban Forestry \& Urban Greening 9:227-233.

Dahle, G., J. Grabosky, B. Kane, J. Miesbauer, W. Peterson, F.W. Telewski, A. Koeser, and G. W. Watson. 2014. Tree biomechanics: A white paper from the 2010 international meeting and research summit at The Morton Arboretum (Lisle, Illinois, U.S.). Arboriculture \& Urban Forestry 40:309-318.

Dahle, G.A., H.H. Holt, W.R. Chaney, T.M. Whalen, D.L. Cassens, R. Gazo, and R.L. McKenzie. 2006. Branch strength loss implications for silver maple (Acer saccharinum) converted from round-over to V-trim. Arboriculture \& Urban Forestry $32: 148-154$.

Day, S., P.E. Wiseman, S.B. Dickinson, and J.R. Harris. 2010. Contemporary concepts of root system architecture of urban trees. Arboriculture \& Urban Forestry 36:149-159

Dean, T.J., and J.N Long. 1986. Validity of constant-stress and elastic instability principles of stem formation in Pinus contorta and Trifolium pratense. Annals of Botany 58:533-840.

De Micco, V., and G. Aronne. 2010. Root structure of Rumex scutatus growing on slopes. IAWA Journal 31:13-28.

Deflorio, G., S. Fink, and F.W.M.R. Schwarze. Detection of incipient decay in tree stems with sonic tomography after wounding and fungal inoculation. Wood Science and Technology 42:117-132.

Detter, A., Richter, K., Rust, C., Rust, S., 2015. Aktuelle Untersuchungen zum Primärversagen von grünem Holz. pp. 156-167 In: D. Dujesiefken (Ed.). Jahrbuch der Baumpflege, Haymarket Media.

Detter, A., Rust, S., Rust, C., Maybaum, G., 2014. Determining strength limits for standing tree stems from bending tests. Proceedings of Non-destructive Testing of Wood Conference (NDTW) 2014, Madison, Wisconsin, U.S.

Dupuy, L., T. Fourcaud, and A. Stokes. 2005. A numerical investigation into the influence of soil type and root architecture on tree anchorage. Plant and Soil 278:119-134.

Dupuy, L.X., T. Fourcaud, P. Lac, and A. Stokes. 2007. A generic 3D finite element model of tree anchorage integrating soil mechanics and real root system architecture. American Journal of Botany 94:1506-1514.

Duryea, M.L., E. Kampf, and R.C. Littell. 2007. Hurricanes and the urban forest: I. Effects on Southeastern United States coastal plain tree species. Arboriculture \& Urban Forestry 33:83-97.

England, A.H., Baker, C.J., and S.E. Saunderson. 2000. A dynamic analysis of windthrow of trees. Forestry 173:225-237.

Ennos, A.R. 1994. The biomechanics of root anchorage. Biomimetics 2:129-137.

Ennos, A.R. 2000. The mechanics of root anchorage. Advances in Botanical Research 33:133-157.

Evans, J.W., J.F. Senft, and D.W. Green. 2000. Juvenile wood effect in red alder: Analysis of physical and mechanical data to delineate juvenile and mature wood zones. Forest Products Journal 50:75-87. 
Fourcaud, T., J-N. Ji, Z-Q. Zhang, and A. Stokes. 2008. Understanding the impact of root morphology on uprooting mechanisms: A modelling approach. Annals of Botany 101:1267-1280.

Genet, M.A. Stokes, F. Salin, S.B. Mickovski, T. Fourcaud, J.F. Dumail, and R. van Beek. 2005. The influence of cellulose content on tensile strength in tree roots. Plant and Soil 278:1-9.

Ghani, M.A., A. Stokes, and T. Fourcaud. 2009. The effect of root architecture and root loss through trenching on the anchorage of tropical urban trees (Eugenia grandis Wight). Trees 23:197-209.

Gibbs, N.J., and B.J.W. Greig. 1990. Survey of parkland trees and the great storm of 16 October 1987. Arboricultural Journal 14:321-347.

Gilbert, E.A., and E.T. Smiley. 2004. Picus sonic tomography for the quantification of decay in white oak (Quercus alba) and hickory (Carya spp.). Journal of Arboriculture 30:277-281.

Gilman, E.F., and F. Masters. 2010. Effect of tree size, root pruning, and production method on root growth and lateral stability of Quercus virginiana. Arboriculture \& Urban Forestry 36:281-291.

Gordon, J.E. 1991. The new science of strong materials. second edition. Penguin Books, New York, New York, U.S. 288 pp.

Greenhill, A.G. 1881. Determination of the greatest height consistent with stability that a vertical pole or mast can be made, and of the greatest height to which a tree of given proportions can grow. Proceedings of the Cambridge Philosophical Society 4:65-73.

Groom, L., L. Mott, and S. Shaler. 2002a. Mechanical properties of individual southern pine fibers. Part I. Determination and variability of stress-strain curves with respect to tree height and juvenility. Wood Fiber Science 34:14-27.

Groom, L., S. Shaler, and L. Mott. 2002b. Mechanical properties of individual southern pine fibers. Part III: Global relationships between fiber properties and fiber location within an individual tree. Wood Fiber Science 34:238-250.

Gruber, F. 2008. Untenable failure criteria for trees: I. The residual wall thickness rule. Arboricultural Journal 31:5-18.

Hale, S., B. Gardiner, A. Wellpott, B. Nicoll, and A. Achim. 2010. Wind loading of trees: Influence of tree size and competition. European Journal of Forest Research 131:203-217.

Harja, D., G. Vincent. R. Mulia, and M. van Noordwiju. 2012. Tree shape plasticity in relation to crown exposure. Trees 26:1275-1285.

Hauer, R.J., J.O. Dawson, and L.P. Werner. 2006. Trees and Ice Storms: The Development of Ice Storm-Resistant Urban Tree Populations, Second Edition. Joint Publication 06-1, College of Natural Resources, University of Wisconsin-Stevens Point, and the Department of Natural Resources and Environmental Sciences and the Office of Continuing Education, University of Illinois at Urbana-Champaign. $20 \mathrm{pp}$.

Haygreen, J.G., and J.L Bowyer. 1982. Forest Products and Wood Science. Iowa State University Press, Ames, Iowa, U.S. 495 pp.

Hesse, L., T. Masselter, J. Leupold, N. Spengler, T. Speck, and J.G. Korvink. 2016. Magnetic resonance imaging reveals functional anatomy and biomechanics of a living dragon tree. Scientific Reports 6:32685.

Hibbeler, R.C. 2005. Mechanics of Material, sixth edition. Pearson Prentice-Hall, Upper Saddle River, New Jersey, U.S. 896 pp.

International Tree Failure Database. 2014. Accessed 11 March 2014. $<$ http://ftcweb.fs.fed.us/natfdb $>$
Jaffe, M.J. 1973. Thigmomorphogenesis: The response of plant growth and development to mechanical stimulation. Planta 114:143-157.

Jaffe, M. 1976. Thigmomorphogenesis electrical resistance and mechanical correlates of the early events of growth retardation due to mechanical stimulation in beans. Zeitschrift für Pflanzenphyiologie 78:24-32.

James, K.R., G.A. Dahle, J. Grabosky, B. Kane, and A. Detter. 2014. Tree biomechanics literature review: Dynamics. Arboriculture \& Urban Forestry 40:1-15.

James K.R., N. Haritos, P.K. Ades. 2006. Mechanical stability of trees under dynamic loads. American Journal of Botany 93:1522-1530.

Jaouen, G., M. Fournier, and T. Almeras. 2010. Thigmomorphogenesis versus light in biomechanical growth strategies of saplings of two tropical rain forest tree species. Annals of Forest Science 67:211-216.

Jessome, A.P. 1977. Strength and related properties of woods grown in Canada. Eastern Forest Products Laboratory, Ottawa, Ontario. Forestry Technical Report 21, Ottawa.

Ji, J., T. Fourcaud, and Z. Zhang. 2007. Towards simulating the biomechanical acclimation of tree roots using numerical analyses. Second International Symposium on Plant Growth Modeling and Applications 78-81.

Johnstone, D., G. Moore, M. Tausz, and M. Nicolas. 2010. The measurement of wood decay in landscape trees. Arboriculture \& Urban Forestry 36:121-127.

Kamimura, K., K. Kitagawa, S. Saito, and H. Mizunaga. 2011. Root anchorage of hinoki [Chamaecyparis obtuse (Sieb. et Zucc.) Endl.] under the combined loading of wind and rapidly supplied water on soil: Analyses based on tree-pulling experiments. European Journal of Forest Research 131:219-227.

Kane, B. 2007. Branch strength of Bradford pear (Pyrus calleryana var. 'Bradford'). Arboriculture \& Urban Forestry 33:283-291.

Kane, B. 2008. Tree failure following a windstorm in Brewster, Massachusetts, USA. Urban Forestry \& Urban Greening 7:15-23.

Kane, B. 2014. Determining parameters related to the likelihood of failure of red oak (Quercus rubra L.) from winching tests. Trees 28:1667-1677.

Kane, B., and P. Clouston. 2008. Tree pulling tests of large shade trees in the genus Acer. Arboriculture \& Urban Forestry 34:101-109.

Kane, B., and J.T. Finn. 2014. Factors affecting branch failures in open-grown trees during a snowstorm in Massachusetts, USA. SpringerPlus 2014 3:720.

Kane, B., and H.D.P. Ryan. 2003. Examining formulas that assess strength loss due to decay in trees: Woundwood toughness improvement in red maple (Acer rubrum). Journal of Arboriculture 29:209-217.

Kane, B., and H.D.P. Ryan. 2004. The accuracy of formula used to assess strength loss due to decay in trees. Journal of Arboriculture 30:347-356.

Kern, K.A., F.W. Ewers, F.W. Telewski, and L. Koehler. 2005. Mechanical perturbation affects conductivity, mechanical properties, and aboveground biomass of hybrid poplars. Tree Physiology 25:1243-1251.

Khuder, H., A. Stokes, F. Danjon, K. Gouskou, and F. Lagane. 2007. Is it possible to manipulate root anchorage in young trees? Plant Soil 294:87-102. 
King, D.A. 1986. Tree form, height growth, and susceptibility to wind damage in Acer saccharum. Ecology 67:980-990.

King, D.A. 1996. Allometry and life history of tropical trees. Journal of Tropical Ecology 12:25-44.

Krause, C., A. Lemay, S. Tremblay, J-C. Ruel, and P.Y. Plourde. 2014. How does the root system inhibit windthrow in thinned black spruce sites in the boreal forest? Trees 28:1723-1735.

Kretschmann, D.E. 2010. Mechanical properties of wood. In: Wood handbook: Wood as an engineering material. General Technical Report FPL-GTR-190. USDA, Forest Products Laboratory, Madison, Wisconsin, U.S.

Lavandjara, M., and H.C. Müller-Lanndau. 2010. Comparison of decay classification, knife test, and two penetrometers for estimating wood density of coarse woody debris. Canadian Journal Forest Research 40:2313-2321.

Lavers, G.M. 1983. The strength properties of timber. Building Research Establishment Report, HMSO, London, UK. 60 pp.

Lichtenegger, H., A. Reiterer, S.E. Stanzl-Tschegg, and P. Fratzl. 1999. Variation of cellulose microfibril angles in softwoods and hardwoods-A possible strategy of mechanical optimization. Journal of Structural Biology 128:257-269.

Lindenmayer, A. 1968. A mathematical model for cellular interactions in development I. Filaments with one-sided inputs. Journal of Theoretical Biology 18:280-299.

Lindström, H., J.W. Evans, and S.P. Verril. 1998. Influence of cambial age and growth condition on microfibril angle in young Norway spruce [Picea abies (L.) Karst.]. Holzforschung 52:573-581.

Löchteken, H., and S. Rust. 2015. Analyse optischer Verfahren zur Messung der Randfaser für die Verwendung bei baumstatischen Untersuchungen. In: D. Dujesiefken (Ed.). Jahrbuch der Baumpflege, Haymarket Media. pp. 267-292.

Lundström, T., T. Jonas, V. Stöckli, and W. Ammann. 2007. Anchorage of mature conifers: Resistive turning moment, root-soil plate geometry, and root growth orientation. Tree Physiology 27:1217-1227.

Lundström, T., M. Stoffel, and V. Stöckli. 2008. Fresh-stem bending of silver fir and Norway spruce. Tree Physiology 28:355-366.

Lundström, T., M. Jonsson, A. Volkwein, and M. Stoffel. 2009. Reactions and energy absorption of trees subjected to rockfall: A detailed assessment using a new experimental method. Tree Physiology 29:345-359.

Mäkelä, A. 2002. Derivation of stem taper from the pipe theory in a carbon balance framework. Tree Physiology 22:891-905.

Mattheck, C., and K. Bethge. 2000. Simple mathematical approaches to tree biomechanics. Arboricultural Journal 24:307-326.

Mattheck, C., K. Bethge, and D. Erb. 1993. Failure criteria for trees. Arboricultural Journal 17:201-209.

Mattheck C., K. Bethge, and P.W. West. 1994. Breakage of hollow tree stems. Trees-Structure and Function 9:47-50.

Mattheck, C., M. Teschner, and J. Schäfer. 1997. Mechanical control of root growth: A computer simulation. Journal of Theoretical Biology 184:261-269.

Mattia, C., F.B. Bischetti, and F. Gentile. 2005. Biotechnical characteristics of root systems on typical Mediterranean species. Plant and Soil 278:23-32.

Mattson, K.D., and F.E. Putz. 2008. Sand pine (Pinus clausa) seedling distribution and biomechanics in relation to microsite conditions and proximity to potential nurse plants. Forest Ecology \& Management 255:3778-3782.
McMahon, T.A. 1975. Using body size to understand the structural design of animals: Quadrupedal locomotion. Journal of Applied Physiology 39:619-627.

McMahon, T.A., and R.E. Kronauer. 1976. Tree structures: Deducing the principle of mechanical design. Journal of Theoretical Biology 59:443-466.

Mencuccini, M., J. Grace, and M. Fioravanti. 1997. Biomechanical and hydraulic determinants of tree structure in Scots pine: Anatomical characteristics. Tree Physiology 17:105-113.

Mergen, F. 1954. Mechanical aspects of wind-breakage and windfirmness Journal of Forestry 52:119-125.

Mickovski, S.B., and A.R. Ennos. 2003. Anchorage and asymmetry in the root system of Pinus peuce. Silva Fenn 37:161-173.

Milne, R., and P. Blackburn. 1989. The elasticity and vertical distribution of stress within stems of Picea sitchensis. Tree Physiology 5:195-205.

Moore, J.R. 2000. Differences in maximum resistive bending moments of Pinus radiata trees grown on a range of soil types. Forest Ecology and Management 135:63-71.

Mott, L., L. Groom, and S. Shaler. 2002. Mechanical properties of individual southern pine fibers. Part II. Comparison of earlywood and latewood fibers with respect to tree height and juvenility. Wood Fiber Science 34:221-237.

Nicoll, B.C., and D. Ray. 1996. Adaptive growth of tree root systems in response to wind action and site conditions. Tree Physiology 16:891-898.

Nicoll, B.C., B.A. Gardiner, B. Rayner, and A.J. Peace. 2006a. Anchorage of coniferous trees in relation to species, soil type and rooting depth. Canadian Journal of Forest Research 36:1871-1883.

Nicoll, B.C, S. Berthier, A. Achim, K. Gouskou, F. Danjon, and L.P.H. van Beek. 2006b. The architecture of Picea sitchensis structural root systems on horizontal and sloping terrain. Trees 20:701-712.

Nicolotti, G., L.V. Socco, R. Martinis, A. Godio, and L. Sambuelli. 2003. Application and comparison of three tomographic techniques for detection of decay in trees. Journal of Arboriculture 24:297-302.

Nielsen, C.C.N. 2010. A comparison of sinker root development in urban and forest trees. In: G.W. Watson, L. Costello, B. Scharenbroch, and E. Gilman (Eds.). The landscape below ground III Proceedings of an international workshop on tree root development in urban soils. International Society of Arboriculture, Champaign, Illinois, U.S. 357 pp.

Niklas, K.J. 1992. Plant biomechanics: an engineering approach to plant form and function. University of Chicago Press, Chicago, Illinois, U.S. 622 pp.

Niklas, K.J. 1994a. Allometry: The scaling of form and process. University of Chicago Press, Chicago, Illinois, U.S. 412 pp.

Niklas, K.J. 1994b. The allometry of safety factors for plant height. American Journal of Botany 81:345-351.

Niklas, K.J. 1995. Size-dependent allometry of tree height, diameter, and trunk-taper. Annals of Botany 75:217-227.

Niklas, K.J. 1997a. Mechanical properties of black locust (Robinia pseudoacacia L.) wood. Size- and age-dependent variation in sap- and heartwood. Annals of Botany 79:265-272.

Niklas, K.J. 1997b. Size- and age-dependent variation in the properties of sap- and heartwood in black locust (Robinia pseudoacacia L.). Annals of Botany 79:473-478. 
Niklas, K.J. 1997c. Mechanical properties of black locust (Robinia pseudoacacia L.) wood: correlations among elastic and rupture moduli, proportional limit, and tissue density and specific gravity. Annals of Botany 79:479-485.

Niklas, K.J. 2000. Computing factors of safety against wind-induced tree damage. Journal of Experimental Botany 51:797-806.

Niklas, K.J. 2002, Wind, Size and Tree Safety. Journal of Arboriculture 28:84-93.

Niklas, K.J., and H.-C. Spatz. 2010. Worldwide correlations of mechanical properties and green wood density. American Journal of Botany 97:1587-1594.

Niklas, K.J., and H.-C. Spatz. 2012. Plant Physics. University of Chicago Press, Chicago, Illinois, U.S. 426 pp.

O'Brien, S.T., S.P. Hubbell, P. Spiro, R. Condit, and R.B Foster. 1995. Diameter, height, crown, and age relationships in eight neotropical tree species. Ecology 76:1926-1939.

Onoda, Y., A.E. Richards, and M. Westoby. 2010. The relationship between stem biomechanics and wood density is modified by rainfall in 32 Australian wood plant species. New Phytologist 185:493-501.

Osunkoya, O.O., K. Omar-Ali, N. Amit, J. Dayan, D.S. Daud, and T.K. Sheng. 2007. Comparative height-crown allometry and mechanical design in 22 tree species of Kuala Belalong rainforest, Brunei, Borneo. American Journal of Botany 94:1951-1962.

Ow, L.F., F.R. Harnas, I.G.B. Indrawan, A. Sahadewa, E.K. Sim, H. Rahardjo, E.C. Leong, Y.K. Fong, and P.Y. Tan. 2010. Treepulling experiment: An analysis into the mechanical stability of rain trees. Trees 24:1007-1015.

Panshin, A.J., and C. de Zeeuw. 1980. Textbook of wood technology. McGraw-Hill, New York, New York, U.S. 722 pp.

Peltola, H.M. 2006. Mechanical stability of trees under static loads. American Journal of Botany 93:1501-151.

Petty, J.A., and C. Swain. 1985. Factors influencing stem breakage of conifers in high winds. Forestry 58:75-84.

Petty, J.A., and R. Worrell. 1981. Stability of coniferous tree stems in relation to damage by snow. Forestry 54:115-128.

Pfisterer, J., and H.-Ch. Spatz. 2012. Ein Katalog der Steifigkeit und Festigkeit für Holz von Laubbäumen: Beziehungen zwischen mechanischen Eigenschaften frischer Hölzer aus verschiedenen Klimazonen und deren Dichte. AFZ DerWald 8:41-45.

Pilate, G., A. Déjardin, F. Laurans, and JC. Leplé. 2004. Tension wood as a model for functional genomics of wood formation. New Phytologist 164:63-72.

Plomion, C., F. Leprovost, and A. Stokes. Wood Formation in Trees. Plant Physiology 127:1513-1523.

Pluciński, M., S. Pluciński, and I. Rodíguez-Iturbe. 2008. Consequence of the fractal architecture of trees on their structural measures. Journal of Theoretical Biology 251:82-92.

Pratt, R.B., A.L. Jacobsen, F.W. Ewers, and S.D. Davis. 2007. Relationship among xylem transport, biomechanics and storage in stems, and roots of nine Rhamnaceae species of the California chaparral. New Phytologist 174:787-798.

Pruyn, M.L., B.J. Ewers, and F.W. Telewski. 2000. Thigmomorphogensesis: Changes in the morphology and mechanical properties of two Populus hybrid in response to mechanical perturbation. Tree Physiology 20:535-540.

Putz, F.E., P.D. Coley, K. Lu, A. Montalvo, and A. Aiello. 1983. Uprooting and snapping of trees: Structural and ecological consequences. Canadian Journal of Forest Research 13:1011-1020.
Rahardjo, H., F.R. Harnas, I.G.B. Indrawan, E.C. Leong, P.Y. Tan, Y.K. Fong, and L.F. Ow. 2013. Understanding the stability of Samanea saman trees through tree pulling, analytical calculations, and numerical models. Urban Forestry \& Urban Greening 13:355-364.

Ray, D., and B.C. Nicoll. 1998. The effect of soil water-table depth on root-plate development and stability of Sitka spruce. Forestry 71:169-182.

Read, J., and A. Stokes. 2006. Plant biomechanics in an ecological context. American Journal of Botany 93:1546-1565.

Rich, P.M., K. Helenurm, D. Kearns, S.R. Morse, M.W. Palmer, and L. Short. 1986. Height and stem diameter relationships for dicotyledonous trees and arborescent palms of Costa Rican tropical wet forest. Bulletin of the Torrey Botanical Club 113:241-246.

Rogers, M., A. Casey, C. McMenamin. 1995. An experimental investigation of the effects of dynamic loading on coniferous trees planted on wet mineral soils. pp. 204-219 In: M.P. Coutts and J. Grace (Eds.). Wind and Trees. Cambridge University Press, Cambridge.

Rosłon-Szeryńska, E., and M. Kosmala 2007. Shape analysis for broke and fallen trees. Annals of Warsaw University of Life Science Horticulture and Landscape Architecture 28:147-157.

Rudnicki, M., U. Silins, and V.J. Lieffers. 2004. Crown cover is correlated with relative density, tree slenderness, and tree height in lodgepole pine. Forest Science 50:356-363.

Ruel, J-C., A. Achim, R.E. Herrera, and A. Cloutier. 2010. Relating mechanical strength at the stem level to values obtained from defect-free wood samples. Trees 24:1127-1135.

Sani, L., R. Lisci, D. Sarri, M. Rimediotti, M. Vieri, and S. Tofanelli. 2012. Preliminary experiments and verification of controlled pulling tests for tree stability assessments in Mediterranean urban areas. Biosystems Engineering 112:218-226.

Schwarze, F.W.M.R. 2008. Diagnosis and Prognosis of the Development of Wood Decay in Urban Trees. ENSPEC, Australia. 336 pp.

Schwarze, F.W.M.R., D. Lonsdale, and S. Fink. 1997. An overview of wood degradation patterns and their implications for tree hazard assessment. Arboricultural Journal 21:1-32.

Schwarze, F.W.M.R., J. Egnels, and C. Mattheck. 2000. Fungal strategies of wood decay in trees. Springer, Berlin, Germany. 185 pp.

Sebera, V., J. Kunecký, L. Praus, J. Tippner, and P. Horáček. Strain transfer from xylem to bark surface analyzed by digital image correlation. Wood Science \& Technology < doi: 10.1007/s00226016-0819-z>

Sebera, V., L. Praus, J. Tippner, J. Kunecký, J. Ćepela, and R. Wimmer. 2014. Using optical full-field measurement based on digital image correlation to measure strain on a tree subjected to mechanical load. Trees 28:1173-1184

Seifert, T., M. Nickel, and H. Pretzsch. 2010. Analyzing the longterm effects of artificial pruning of wild cherry by computer tomography. Trees 24:797-808.

Sinn, G. 1990. Untersuchungen zur Kippursache von Eichen im Riederwald Frankfurt/M. Bd. LP 25. Schriftenreihe Taxationspraxis. SVK-Verlag, Erndtebrück 199S.

Sinn, G., and L. Wessolly. 1989. Baumstatik - zwei neue zerstörungsfreie Messverfahren. Teil 1: Ermittlung der Stand- und Bruchsicherheit von Bäumen durch Messung. Das Gartenamt $38: 422-428$

Smiley, E.T. 2008. Root pruning and stability of young willow oak. Arboriculture \& Urban Forestry 34:123-128. 
Smiley, E.T., and B.R. Fraedrich. 1992. Determining strength loss from decay. Journal of Arboriculture 18:201-204.

Smiley, E.T., L. Holmes, and B.R. Fraedrich. 2014. Pruning of buttress roots and stability changes of red maple (Acer rubrum). Arboriculture \& Urban Forestry 40:230-236.

South D.B., J. Shelton, and S.A. Enebak. 2001. Geotropic lateral roots of container-grown longleaf pine seedlings. Native Plants Journal 2:126-130

Spatz, H.C., H. Beismann, F. Brüchert, A. Emanns, and T. Speck. 1997. Biomechanics of the giant reed Arundo donax. Philosophical Transactions of the Royal Society of London 352:1-10.

Spatz, H.C., and F. Brüchert. 2000. Basic biomechanics of selfsupporting plants: Wind and gravitational loads on a Norway spruce tree. Forest Ecology Management 135:33-44.

Spatz, H.C., and J. Pfisterer. 2013. Mechanical properties of green wood and their relevance for tree risk assessment. Arboriculture \& Urban Forestry 39:218-225.

Spatz, H.C., and K.J. Niklas. 2013. Modes of failure in tubular plant organs. American Journal of Botany 100:332-336.

Spatz, H.C., F. Brüchert, and J. Pfisterer. 2007. Multiple resonance damping or how do trees escape dangerously large oscillations? American Journal of Botany 94:1603-1611.

Spatz, H.C., and T. Speck. 1994 Local buckling and other modes of failure in hollow plant stems. Biomimetics 2:149-173.

Speck, T., and I. Burgert. 2011. Plant stems: Functional design and mechanics. Annual Review of Materials Research 41:169-93.

Sposito, T.C., and F.A.M. Santos. 2001. Scaling of stem and crown in eight Cecropia (Cecropiaceae) species of Brazil. American Journal of Botany 88:939-949.

Stokes, A. 1999. Strain distribution during anchorage failure in root systems of maritime pine (Pinus pinaster Ait.) at different ages and tree growth response to wind-induced root movement. Plant Soil 217:17-27.

Stokes, A., S. Berthier, S. Sacriste, and F. Martin. 1998. Variations in maturation strains and root shape in root systems of Maritime pine (Pinus pinaster Ait.). Trees 12:334-339.

Suzuki, A.A., and M. Suzuki. 2009. Why do lower order branches show greater shoot growth than higher order branches? Considering space availability as a factor affecting shoot growth. Trees 23:69-77.

Telewski, F.W. 2006. A unified hypothesis of mehanoperception in plants. American Journal of Botany 93:1466-1476.

Telewski, F.W. 1990. Growth, wood density, and ethylene production in response to mechanical perturbation in Pinus taeda. Canadian Journal of Forest Research 20:1277-1282.

Telewski, F.W., and M.J. Jaffe. 1986a. Thigmomorphogenesis: The role of ethylene in the response of Pinus taeda and Abies fraseri to mechanical perturbation. Physiologia Plantarium 66:227-233.

Telewski, F.W., and M.J. Jaffe. 1986b. Thigmomorphogenesis: Anatomical, morphological, and mechanical analysis of genetically different sibs of Pinus taeda in response to mechanical perturbation. . Physiologia Plantarium 66:219-226.

Telewski, F.W., and M.L. Pruyn. 1998. Thigmomorphogenesis: a dose response to flexing in Ulmus americana seedlings. Tree Physiology 18:65-68.

Terho, M., and A.M. Hallaksela. 2005. Potential hazard characteristics of Tilia, Betula, and Acer trees removed in the Helsinki City area during 2001-2003. Urban Forestry \& Urban Greening 3(2):113-120.
Thibaut, B., J. Gril, and M. Fournier. 2001. Mechanics of wood and trees: Some new highlights for an old story. CR Acad Sci Paris 329:701-716.

Tobin, B., J. Čermák, C. Chiatante, F. Danjon, A. Di Iorio, L. Dupuy, A. Eshel, et al. 2007. Towards developmental modeling of tree root systems. Plant Biosystems 141:481-501.

Urban, S.T., V.J. Leiffers, and S.E. Macdonald. 1994. Release in radial growth in the trunk and structural roots of white spruce as measured by dendrochronology. Canadian Journal of Forest Research 24:1550-1556.

van Gelder, H.A., L. Poorter, and F.J. Sterck. 2006, Wood mechanics, allometry, and life-history variation in a tropical rain forest tree community. New Phytologist 171:367-378.

van Wassenaer, P., and M. Richardson. A review of tree risk assessment using minimally invasive technologies and two case studies. Arboricultural Journal 32:275-292.

Vanomsen, P. 2006. Der Einfluss der Durchforstung auf die Verankerung der Fichte hinsichtlich ihrer Sturmresistenz.

Vogel, S. 1996. Blowing in the wind: Storm resisting feature of the design of trees. Journal of Arboriculture 22:92-92.

Wagener, W.W. 1963. Judging hazards from native trees in California recreational areas: A guide for professional foresters. USFS Research Paper PSW-P1. 29 pp.

Wang, X., and R.B. Allison. 2008. Decay detection in red oak trees using a combination of visual inspection, acoustic testing, and resistance microdrilling. Arboriculture \& Urban Forestry 31:1-4.

Wang, Y., S.J. Titus, and V.M. LeMay. 1998. Relationship between tree slenderness coefficients and tree or stand characteristics for major species in boreal mixedwood forests. Canadian Journal of Forest Research 28:1171-1183.

Watson, A. 2000. Wind-induced forces in the near-surface lateral roots of radiata pine. Forest Ecology and Management 135:133-142.

Watson, A., and J.D. Tombleson 2002. Toppling in juvenile pines: A comparison of the root system characteristics of direct-sown seedlings, and bare-root seedlings and cuttings. Plant and Soil 239:187-196.

Wessolly, L. 1991. Verfahren zur Bestimmung der Stand- und Bruchsicherheit von Bäumen. Holz als Roh- und Werkstoff 49:99-104.

Wessolly, L. 1994. Wurzelschäden und Standsicherheit von Bäumen. Neue Landschaft 39:853-860.

Wessolly, L. 1996. Standsicherheit von Bäumen. Stadt und Grün 4:268-272.

Wessolly, L., and M. Erb 1998. Handbuch der Baumstatik und Baumkontrolle. Patzer Verlag, Berlin, Germany.

Wiedenhoeft, A. 2010. Structure and function of wood. In: Wood Handbook: Wood as an engineering material. General Technical Report FPL-GTR-190. USDA, Forest Products Laboratory, Madison, Wisconsin, U.S

Wilcox, W.W. 1978. Review of literature on the effects of early stages of decay on wood strength. Wood and Fiber Science 9:252-257.

Williamson, G.B., and M.C. Wiemann. 2010. Measuring wood specific gravity-Correctly. American Journal of Botany 97:519-524.

Woodcock, D.W., and A.D. Shier. 2003. Does canopy position affect wood specific gravity in temperate forest trees? Annals of Botany 91:529-537. 
Woodrum, C.L., F.W. Ewers, and F.W. Telewski. 2003. Hydraulic, biomechanical, and anatomical interactions of xylem from five species of Acer (Aceraceae). American Journal of Botany 90:693-699.

Yang, M., P. Défossez, F. Danjon, and T. Fourcaud. 2014. Tree stability under wind: Simulating uprooting with root breakage using a finite element method. Annals of Botany < doi: 10.1093/aob/ mcu122>

Yoshida, M., T. Okuyama, H. Yamamoto, and K. Sugiyama. 1992. Tree form and internal stresses II. Stresses around the base of a branch. Mokuzai Gakkaishi 38:657-662.

Zabel, R.A., and J.J. Morrell. 1992. Wood microbiology: Decay and its prevention. Academic Press, London, UK, and New York, U.S.

Zobel, B.J., and J.P. van Buijtenen. 1989. Wood Variation. SpringerVerlag, Berlin, Germany.

Gregory A. Dahle1 (corresponding author)

Davis College, School of Natural Resources,

West Virginia University

Morgantown, West Virginia 26506, U.S.

gregory.dahle@mail.wvu.edu

Kenneth R. James

Research Engineer, ENSPEC, Australia, and

Fellow, Faculty of Science

University of Melbourne

Australia

Brian Kane

University of Massachusetts

Amherst, Massachusetts, U.S.

Jason Grabosky

Rutgers University

Ecology Evolution Nat Resources

14 College Farm Road

New Brunswick, New Jersey 08901, U.S.

Andreas Detter

Brudi and Partner

Tree Consult

Gauting, Germany

Résumé. Au cours des 30 dernières années, les chercheurs ont commencé à utiliser des principes biomécaniques pour comprendre la stabilité des arbres urbains. Cette revue de littérature s'est concentrée sur les ouvrages relatifs aux arbres des milieux urbains tempérés, mais a également inclut des documents provenant d'autres disciplines et climats selon leur pertinence. La capacité de charge (ou portante) d'un arbre dépend de sa taille, de sa forme et des propriétés matérielles de son bois. À mesure que le tronc et les branches augmentent en diamètre, leur capacité de charge s'accroît. Les propriétés matérielles (par exemple, les coefficients d'élasticité et de rupture) qualifient la rigidité et la résistance intrinsèque du bois, qui influent respectivement sur la déflexion sous charge et la capacité de charge. Dans le bois, les propriétés matérielles varient en fonction de divers facteurs, dont la direction de la charge, la teneur en humidité et l'âge de l'arbre. La carie du bois réduit la capacité de charge d'un arbre. Bien que les praticiens aient élaboré des lignes directrices pour évaluer son impact, ces règles existantes devraient être analysées, améliorées ou rejetées sur la base de tests scientifiques rigoureux. Des tests de charge statique ont été développés pour répondre à cette question, ainsi que pour analyser la probabilité de déracinement (chablis) qui représente jusqu'à $35 \%$ des défaillances d'arbres. Bien que l'on ait beaucoup appris, plusieurs questions demeurent quant à la capacité de charge statique des arbres croissant en milieu urbain.

Zusammenfassung. Über die letzten 30 Jahre haben Forscher angefangen, zum besseren Verständnis von der Stabilität von Bäumen, biomechanische Prinzipien hinzuzuziehen. Dieser Rückblick konzentriert sich auf die Literatur über Bäume in gemäßigt temperierten urbanen Landschaften, aber es schließt auch relevante Arbeiten aus anderen Disziplinen und Klimaten ein, die hierzu passen. Die lasttragende Fähigkeit von Bäumen ist von der Größe, Form und den Materialeigenschaften des Holzes abhängig. Wenn der Stamm und die Äste im Durchmesser zunehmen, steigen auf ihre lasttragenden Fähigkeiten. Die Materialeigenschaften (z.B. Moduli der Elastizität und Bruchfähigkeit) beschreiben im Wesentlichen die Holzsteife und Stärke, welche die Biegung unter Last und die lasttragenden Fähigkeiten von Holz beeinflussen. Im Holz können die Materialeigenschaften in Relation zu einer Reihe von Faktoren variieren, einschließlich der Richtung der Last, Feuchtigkeitsgehalt und Baumalter. Holzfäule reduziert die lasttragende Fähigkeit von Bäumen. Obwohl die Praktiker Richtlinien entwickelt haben, um diesen Effekt zu untersuchen, sollten die existierenden Richtlinien auf der Basis einer rigorosen wissenschaftlichen Prüfung untersucht, verbessert oder verworfen werden. Um dieser Fragestellung zu begegnen, wurden Tests zur statischen Last entwickelt, wie auch Untersuchungen zur Wahrscheinlichkeit von Entwurzelungen, die bei bis zu $35 \%$ allen Baumversagens eine Rolle spielt. Während viel gelernt wurde, bleiben dennoch viele Fragen zur statischen lasttragenden Fähigkeit von Bäumen in urbanen Landschaften bestehen.

Resumen. En los últimos 30 años, los investigadores han comenzado a emplear principios biomecánicos para comprender la estabilidad de los árboles urbanos. Esta revisión se centra en la literatura referente a los árboles en los paisajes urbanos templados, pero también incluye trabajo relevante de otras disciplinas y climas según sea apropiado. La capacidad de carga de un árbol depende de su tamaño y forma y de las propiedades del material de su madera. A medida que el tronco y las ramas aumentan de diámetro, su capacidad de carga aumenta. Las propiedades del material (por ejemplo, módulos de elasticidad y rotura) describen rigidez y resistencia intrínseca de la madera, que influyen en la deflexión bajo carga y la capacidad de carga, respectivamente. En la madera, las propiedades del material varían en relación con una variedad de factores, incluyendo la dirección de la carga, el contenido de humedad y la edad del árbol. El decaimiento de la madera reduce la capacidad de carga de un árbol. Aunque los profesionales han desarrollado lineamientos para evaluar su efecto, las directrices existentes deben ser investigadas, refinadas o rechazadas sobre la base de pruebas científicas rigurosas. Se han desarrollado pruebas de carga estática para abordar esta cuestión, así como investigar la probabilidad de desenraice, que representa hasta un 35\% de los fracasos de los árboles. Aunque se ha aprendido mucho, subsisten muchas cuestiones sobre la capacidad de carga estática de los árboles que crecen en los paisajes urbanos. 